Journal Wetenskap Health

\title{
The Effect of Work Satisfaction and Leadership on Patient Safety Culture in Nurses at Lagaligo Regional Public Hospital I East Luwu Regency
}

\author{
Achmad Rifai Pandin ${ }^{1}$, Syahrir Pasinringi ${ }^{1}$, Lalu Muhammad Saleh ${ }^{2}$ \\ ${ }^{1}$ Hospital Management Division, Faculty of Public Health, Hasanuddin University, Indonesia \\ ${ }^{2}$ Occupational Health and Safety Section, Faculty of Public Health, Hasanuddin University, \\ Indonesia
}

\begin{abstract}
Realization of the application of patient safety and efforts to fulfill employee job satisfaction through employee development have not met the targets set in the strategic goals for the achievement of hospital quality indicators. This study aims to analyze the effect of job satisfaction based on the dimensions of job characteristics, rewards, work environment, relationship with management and leadership based on directive, supportive, participatory, achievement-oriented dimensions of patient safety culture in nurses at Lagaligo I Hospital, East Luwu Regency. This type of research is a quantitative study using an analytic observational study with a cross sectional study design. The sample used was 119 respondents to nurses at Lagaligo I Hospital, East Luwu Regency. The results showed that there was an influence of job characteristics, rewards, work environment, relationship with management on the variable job satisfaction of nurses on patient safety culture, there was an influence of directive, supportive, participatory, achievement-oriented dimensions on leadership variables on patient safety culture, and job satisfaction of nurses. jointly influence the culture of patient safety in Regional General Hospital (RSUD) I Lagaligo, East Luwu Regency. Therefore, it is hoped that the hospital will pay more attention to a safe and comfortable work environment and for leadership it is expected to set standards for developing competency through trainings, solving any existing problems quickly and responsively.
\end{abstract}

Keywords: Job Satisfaction, Leadership, Patient Safety Culture

\section{Introduction}

The quality of health services has long received global attention. Public demand for quality and affordable health facilities is getting higher and various efforts have been made to meet these expectations. This is because health services are basically aimed at providing satisfaction to patients (Mutsani, 2013).

The services provided by the hospital must be of high quality and meet five main quality dimensions, namely tangibles (direct evidence), reliability (reliability), responsiveness (responsiveness), assurance (assurance), and empathy (empathy). The quality of hospital services can be viewed from two perspectives, namely the quality of service which is assessed based on standards that are more directed at aspects of medical services and from the side of patients or service consumers (non-medical aspects). From the patient side, quality

Article Info:

Received: April 10, 2021

Revised: May 9, 2021

Accepted: May 24, 2021

Copyright (C) 2021, Journal Wetenskap Health, Under the license CC BY-SA 4.0 
can be measured from patient satisfaction because the quality of health services is closely related to patient satisfaction (Veramitha et al., 2016).

To be able to improve services both in terms of quality and quantity, the hospital must have good governance. Both in terms of administration, service and finance. Good governance includes adequate planning, a fast, accurate and integrated information system, a professional work culture, and an appropriate feedback system. With good governance, it is expected that the hospital can work efficiently while maintaining the quality of its services and being able to answer the health service needs needed. Therefore the hospital strives to become a service institution in accordance with the expectations of its patients to meet needs in the context of public services and improve community welfare (Enfoque et al., 2010).

Hospital as a health service provider is responsible for analyzing the system that is run in the organization which aims to achieve patient outcomes (Dicuccio, 2015). One of the most concerned patient outcomes in the entire hospital analysis unit is the problem of patient safety. Patient safety is part of hospital safety, which includes the safety of medical equipment and hospital buildings (equipment and building safety), environment and building safety, hospital business safety. and personal safety in the hospital (personal safety). Patient safety is a top priority for policy makers in the world of health, including service providers and managers (Dicuccio, 2015).

One of the strategies that can be used to reduce incidents related to patient safety in the hospital is by stimulating employee job satisfaction. If something goes wrong, other employees will often blame the person who made the mistake (Duffy, 2017). Therefore, open communication is needed in a team so that there is mutual understanding between staff, then understand what happened and then analyze what factors make staff make mistakes related to patient safety (Duffy, 2017).

One of the relationships that will be easy if employees do their work without being distracted by a bad work environment is the relationship between patient safety and employee job satisfaction which will ultimately result in good performance, which is related to patient safety and performance in other matters (Asegid et al., 2014). In addition, According to Inoue et al., (2017) that the factors affecting care job satisfaction are nurses 'perceptions of autonomy in the workplace and nurses' perceptions of patient safety procedures. Patient safety is a top priority in health services and is a good step to improve the quality of service and quality of hospital services (Depkes, 2008).

The decline in the quality of services provided to patients and the increase in the cost of patient health services occurred due to decreased employee job satisfaction (Asegid et al., 2014). Nurse job satisfaction is measured by external rewards, service schedules, opportunities to develop professionally, rewards or praise, responsibility received, balance between family and work, relationships with other employees and interactions in the work environment.

This is closely related to the basic essence of the hospital, namely meeting the needs and demands of patients who expect solutions to their health problems at the hospital. Patients view that only hospitals are able to provide medical services as an effort to cure and recover from the pain they suffer. Patients expect services that are ready, fast, responsive and comfortable to patient complaints so that hospital human resources must have special skills, including understanding products in depth, looking attractive, being friendly and friendly, responsive (sensitive) to patients, mastering work, communicate effectively and be able to respond to patient complaints in a professional manner (Nurdiana, 2018). 
A review conducted by Richardson, A Storr (2010) about patient safety identifying nurses and nurse leaders is an ideal place to drive changes in the quality of health care that lead to patient safety. For example, researchers have observed a statistically significant association $(\alpha<0.002)$ between perceptions of positive leadership practices in patient safety culture in the medical-surgical care unit and willingness to report errors, a characteristic behavior in safety culture (Moody et al., 2006).

Practical guidelines relating to leadership and patient safety have been developed based on national health care indicators, and national campaigns to save lives have been promoted and supported throughout the United States. (Institute for Healthcare Improvement, 2006.) In Canada, the Canadian Institute for Patient Safety has also completed several initiatives, including the Canadian Incident Analysis Framework and the Safety Competency Framework (Canadian Institute for Patient Safety, n.d.). However, it is evident in the literature review on patient safety outcomes that more needs to be done to maintain patient safety in North American healthcare facilities. Recent evidence related to competence in health care leadership and in promoting and maintaining patient safety reveals a link between key leadership skills and data-driven improvements in staff performance and patient safety outcomes (Bohan \& Laing, 2012; Richardson \& Storr, 2010; Sammer, Lykens, 2010; Singh, Mains, \& Lackan, 2010). The most important thing to improve patient safety in the health care system is to build a culture of trust and organizational learning, so that healthcare providers can learn from mistakes that occur in the health care system (Ring \& Fairchild, 2013).

Research on job satisfaction of nurses in Indonesia conducted at PHC Hospital Surabaya by Cholifah \& Paskarini (2013) states that nurse satisfaction is at a high level in the intensive care room and emergency room at the hospital, namely: in ICU as many as $46.6 \%$ of respondents and in IGD as much as $32.1 \%$. Another research on nurse job satisfaction conducted by Ahsan \& Pradyanti (2015), at Mardi Waluyo Blitar Regional Hospital, showed that out of 61 respondents, 2 people (3.3\%) had low job satisfaction, 42 people (68.9) had job satisfaction. moderate, and only 17 people $(27.9 \%)$ have high job satisfaction. This shows that there are still few nurses in Indonesia and abroad who have a high level of job satisfaction. Research at Hospital Rasht City shows that there is a significant direct relationship between job satisfaction of nurses and patient safety culture with a significant correlation coefficient between 0.643 to 0.01 (Okshaksaraie, 2016). An adequate atmosphere that can increase job satisfaction, can improve patient performance and safety (Plaza et al., 2018) Job satisfaction related to patient safety culture if negative can lead to unexpected incidents.

RSUD I Lagaligo East Luwu Regency is a hospital owned by the regional government which is technically responsible to the Regent through the Regional Secretary of East Luwu Regency. In an effort to maintain the quality of services at the Lagaligo I Hospital, East Luwu Regency on February 24, 2010, it has succeeded in obtaining a basic level full accreditation certificate. Then on 12-13 August 2015, the 2012 version of the new accreditation survey was carried out by the Hospital Accreditation Commission (KARS) survey team, and Lagaligo I Hospital was declared to have successfully passed the Initial Level based on KARS letter No. 2203 / KARS / VIII / 2015 dated 20 August 2015 and received an accreditation certificate that is valid until 11 August 2018. Furthermore, Lagaligo I Hospital in December 2018 was surveyed for accreditation by KARS with SNARS Issue 1 and the evaluation results of RSUD I Lagaligo LULUS LEVEL PARIPURNA according to KARS letter Number: KARSSERT / 270 / XII / 2018 dated December 31, 2018. According to the letter of RSUD I Lagaligo 
number 435/819 / RSUD I Lagaligo dated November 29, 2019 regarding request for verification survey to KARS, and confirmation from KARS according to letter number B / KARSVerif / XII / 2019 dated December 12, 2019 Regarding the hospital verification survey and on December 19, 2019, RSUD I Lagaligo was surveyed for the first verification by KARS with 1 surveyor, then the rest is waiting for recommendations from the results of the survey conducted by KARS.

The implementation of patient safety culture at Lagaligo I Hospital, East Luwu Regency, is known from the strategic objectives in the 2016-2020 OPD Strategic Plan which outlines the percentage of hospital quality indicator achievements on the patient safety quality indicators, it is known that the realization only reached $87.5 \%$ of the $95 \%$ target. In addition, related to the fulfillment of employee job satisfaction, there are indicators that do not meet the target as well, namely the percentage of employees who attend technical guidance/training that the realization only reaches $46 \%$ of the $80 \%$ target.

Table 1. Achievement of Performance Indicators of Lagaligo I Hospital in East Luwu Regency

\begin{tabular}{|c|c|c|c|c|}
\hline No. & Performance Indicators & Target & Realization & Capaian $(\%)$ \\
\hline \multirow[t]{9}{*}{1.} & $\begin{array}{l}\text { Public/patient } \\
\text { satisfaction index } \\
>\text { Percentage of hospital } \\
\text { quality indicator } \\
\text { achievement. }\end{array}$ & & & \\
\hline & $\begin{array}{l}\text { Clinical quality } \\
\text { indicators }\end{array}$ & $86 \%$ & $86,6 \%$ & 99,2 \\
\hline & $\begin{array}{l}\text { Management quality } \\
\text { indicators }\end{array}$ & $87 \%$ & $94,4 \%$ & 87,1 \\
\hline & $\begin{array}{l}>\text { Patient safety quality } \\
\text { indicators }\end{array}$ & $95 \%$ & $87,5 \%$ & 112,9 \\
\hline & $\begin{array}{l}\text { Service } \\
\text { figures: }\end{array}$ & & & \\
\hline & $>$ TOI (turn over interval) & $2 \mathrm{hr}$ & $0,6 \mathrm{hr}$ & 60,0 \\
\hline & $>$ BTO (Bed turn over) & $50 \mathrm{k}$ & $\begin{array}{l}91 \text { at 9:00 } \\
\text { p.m. }\end{array}$ & 182 \\
\hline & $\begin{array}{l}\text { NDR (Hospital net } \\
\text { mortality rate) }\end{array}$ & $17 \%$ & $16 \%$ & 88,9 \\
\hline & $\begin{array}{l}\text { Percentage of service } \\
\text { accreditation elements } \\
\text { that meet hospital } \\
\text { accreditation standards }\end{array}$ & $100 \%$ & $90 \%$ & 90 \\
\hline \multirow[t]{3}{*}{2.} & $>\begin{array}{l}\text { Opinion of financial } \\
\text { statements }\end{array}$ & WTP & WTP & 100 \\
\hline & $\begin{array}{l}\text { Completeness of } \\
\text { performance } \\
\text { accountability reporting }\end{array}$ & $100 \%$ & $100 \%$ & 100 \\
\hline & $\begin{array}{l}\text { Percentage of revenue } \\
\text { contribution to RS } \\
\text { operating costs (CRR) }\end{array}$ & $75 \%$ & & \\
\hline 3. & $>$ Percentage & $80 \%$ & $46 \%$ & 57 \\
\hline
\end{tabular}




\begin{tabular}{|c|c|c|c|c|}
\hline No. & Performance Indicators & Target & Realization & Capaian (\%) \\
\hline & $\begin{array}{l}\text { employees } \\
\text { participated in bimtek } \\
\text { /training }\end{array}$ & & & \\
\hline & $\begin{array}{l}\text { Percentage of hospital } \\
\text { human resources } \\
\text { improvement }\end{array}$ & $70 \%$ & $100 \%$ & 142 \\
\hline & $\begin{array}{l}\text { Percentage of training } \\
\text { fulfillment followed }\end{array}$ & $90 \%$ & $95 \%$ & 105 \\
\hline & $\begin{array}{l}\text { Percentage of health } \\
\text { workers who meet } \\
\text { competency standards }\end{array}$ & $95 \%$ & $100 \%$ & 105 \\
\hline 4. & $\begin{array}{l}\text { The fulfillment of } \\
\text { infrastructure facilities } \\
\text { in accordance with the } \\
\text { standards: }\end{array}$ & & & \\
\hline & $\begin{array}{ll}\text { - Fulfillment of } \\
\text { hospital } \\
\text { infrastructure (new } \\
\text { development) }\end{array}$ & $100 \%$ & $100 \%$ & 100 \\
\hline & $\begin{array}{l}\text { - Implementation of } \\
\text { the procurement of } \\
\text { hospital medical } \\
\text { devices. }\end{array}$ & $100 \%$ & $95 \%$ & 95 \\
\hline & $>$ Calibrated punctuality & $100 \%$ & $100 \%$ & 100 \\
\hline
\end{tabular}

Source: Secondary Data

The results of previous interviews with several nurses can be concluded that the poor working conditions include team work and communication, work environment regarding facilities as well as work stress and job satisfaction of nurses. The hospital has an organizational structure with a clear line of communication, so there is no difficulty in communicating problems, especially issues regarding patient safety, but there is still a culture of shaming and blaming so that there is concern in reporting unexpected incidents and nearinjury events, so that if this happens it only becomes a conversation or is resolved at the managerial level where the incident occurs, only certain incidents are reported but there is never any feedback. Hospital management is committed to improving patient safety culture, but it has not been thoroughly socialized to every employee. The role of the leader in the hospital is also illustrated by their participation in the service management process activities starting from planning, organizing, implementing work, monitoring, and evaluating the work of their employees.

From the evaluation and analysis of the achievement of the targets described above, it can be seen that hard work has been done by RSUD I Lagaligo, East Luwu Regency to ensure the achievement of performance is a priority in regional development. However, several challenges need to be a focus for improving hospital performance. Challenges in health care towards Universal Health Coverage (UHC) which require hospitals to be more professional in management and service management in order to achieve quality services that focus on patients and patient health and the safety of health workers. 
So based on the problem data obtained and the results of previous interviews, it is important to examine the effect of job satisfaction and leadership on patient safety culture because nurses at Lagaligo I Hospital, East Luwu Regency.

\section{Methods}

This research was conducted at Lagaligo I Hospital, East Luwu Regency. This type of research is a quantitative study using an observational study with a Cross Sectional Study approach. The population of this study were all nurses who served in RSUD I Lagaligo, East Luwu Regency, namely 171 people. The sample in this study using stratified random sampling with the type of proportional random sampling is 119 respondents.

The instrument used in data collection was a questionnaire, regarding the independent variables in the form of job satisfaction and leadership while the dependent variable was patient safety culture. Univariate analysis was conducted to obtain an overview of the research problem by describing each variable used in the study and the characteristics of the respondent. Univariate analysis consisted of descriptive analysis of the characteristics of the respondents, descriptive analysis of the research variables and analysis of the crosstabulation between the characteristics of the respondents and the research variables. Bivariate analysis was carried out to see the relationship between two variables, namely between the independent variable and the dependent variable. The statistical test used was the chi square test. Multivariate analysis was carried out on variables that affect patient safety culture in Lagaligo I Hospital, East Luwu Regency. By using a regression test

\section{Results and Discussion}

Table 1. Nurse Characteristics

\begin{tabular}{|l|c|c|}
\hline \multirow{2}{*}{ Characteristic } & \multicolumn{2}{c|}{ Research Samples } \\
\cline { 2 - 3 } Work Unit & 15 & \% \\
\hline IGD & 9 & 72.61 \\
\hline Isolation & 10 & 8.40 \\
\hline ICU & 13 & 10.92 \\
\hline VIP & 6 & 5.04 \\
\hline Class 1 & 6 & 5.04 \\
\hline Class 2 & 40 & 33.61 \\
\hline Class 3 & 9 & 7.56 \\
\hline OK & 6 & 5.04 \\
\hline Perinatology & 5 & 4.20 \\
\hline Support & 25 & 21.01 \\
\hline \multicolumn{3}{|c|}{ Gender } \\
\hline Man & 94 & 78.99 \\
\hline Woman & 41 & 34.45 \\
\hline \multicolumn{3}{|c|}{ Last Education } \\
\hline 21 - 30 years old & 72 & 60.50 \\
\hline 31 - 40 years old & 6.04 \\
\hline$>40$ years old & \\
\hline \multicolumn{2}{|c|}{} \\
\hline
\end{tabular}




\begin{tabular}{|l|c|c|}
\hline \multirow{2}{*}{ Characteristic } & \multicolumn{2}{c|}{ Research Samples } \\
\cline { 2 - 3 } & $\mathbf{n}$ & \% \\
\hline D3/Equivalent & 52 & 43.70 \\
\hline S1/Equivalent & 60 & 50.42 \\
\hline S2/Equivalent Working Period \\
\hline \multicolumn{3}{|c|}{} \\
\hline$<$ 1 year & 7 & 5.88 \\
\hline 1 - 5 years old & 10 & 8.88 \\
\hline 6 - 10 years old & 63 & 52.94 \\
\hline$>10$ years & 39 & 32.77 \\
\hline \multicolumn{3}{|c|}{ Staffing Status } \\
\hline PNS & 42 & 35.29 \\
\hline Service Wages & 62 & 52.10 \\
\hline Volunteers & 15 & 12.61 \\
\hline
\end{tabular}

Source: Primary Data

Table 1 shows the frequency distribution based on the characteristics of the sample at the research location, most of the respondents in the Class 3 Work Unit were 40 respondents (33.61\%). In terms of gender, most of the respondents were female, namely 94 respondents (78.99\%). In terms of age, most of the respondents were 31-40 years old, as many as 72 respondents $(60.50 \%)$. Judging from the latest education, most of the respondents with the latest education were S1 / equivalent, as many as 60 respondents $(50.42 \%)$. Judging from the tenure of work, most of the respondents worked 6 - 10 years, as many as 63 respondents (52.94\%). Judging from the employment status, most of the service wages were 62 respondents $(52.10 \%)$.

Table 2. Research Variables

\begin{tabular}{|c|c|c|}
\hline \multirow{2}{*}{ Variable } & \multicolumn{2}{|c|}{ Research Samples } \\
\hline & $\mathbf{n}$ & $\%$ \\
\hline \multicolumn{3}{|c|}{ Job Satisfaction } \\
\hline Less Satisfied & 6 & 5.04 \\
\hline Satisfied & 113 & 94.96 \\
\hline \multicolumn{3}{|c|}{ Leadership } \\
\hline Less Good & 7 & 5.88 \\
\hline Good & 112 & 94.12 \\
\hline \multicolumn{3}{|c|}{ Patient Safety Culture } \\
\hline Low & 8 & 6.72 \\
\hline Tall & 111 & 93.28 \\
\hline Total & 119 & 100.0 \\
\hline
\end{tabular}

Source: Primary Data

Table 2 explains the percentage of respondents' assessment of the research variables. The results in most of the respondents stated that they were in the category of some respondents stated that the work unit stated that the patient's Job Satisfaction, Leadership, and Safety Culture were high (good). 
Table 3. Effect of Independent Variables with Dependent Variables

\begin{tabular}{|c|c|c|c|c|c|c|c|}
\hline \multirow{3}{*}{ Variables and Dimensions } & \multicolumn{4}{|c|}{ Patient Safety Culture } & \multirow{2}{*}{\multicolumn{2}{|c|}{ Total }} & \multirow{3}{*}{ P-value } \\
\hline & \multicolumn{2}{|r|}{ Low } & \multicolumn{2}{|c|}{ Tall } & & & \\
\hline & $\mathbf{n}$ & $\%$ & $\mathbf{n}$ & $\%$ & $\mathbf{n}$ & $\%$ & \\
\hline \multicolumn{8}{|c|}{ Job Characteristics } \\
\hline Low & 2 & 100.00 & 0 & 0.00 & 2 & 100.00 & \multirow{3}{*}{0.000} \\
\hline Tall & 5 & 4.27 & 112 & 95.73 & 117 & 100.00 & \\
\hline Total & 7 & 5.88 & 112 & 94.12 & 119 & 100.00 & \\
\hline \multicolumn{8}{|c|}{ Appreciation } \\
\hline Low & 7 & 17.95 & 32 & 82.05 & 39 & 100.00 & \multirow{3}{*}{0.000} \\
\hline Tall & 0 & 0.00 & 80 & 100.00 & 80 & 100.00 & \\
\hline Total & 7 & 5.88 & 112 & 94.12 & 119 & 100.00 & \\
\hline \multicolumn{8}{|c|}{ Work Environment } \\
\hline Low & 2 & 66.67 & 1 & 33.33 & 3 & 100.00 & \multirow{3}{*}{0.000} \\
\hline Tall & 5 & 4.31 & 111 & 95.69 & 116 & 100.00 & \\
\hline Total & 7 & 5.88 & 112 & 94.12 & 119 & 100.00 & \\
\hline \multicolumn{8}{|c|}{ Relationship with Management } \\
\hline Low & 5 & 33.33 & 10 & 66.67 & 15 & 100.00 & \multirow{3}{*}{0.000} \\
\hline Tall & 2 & 1.92 & 102 & 98.08 & 104 & 100.00 & \\
\hline Total & 7 & 5.88 & 112 & 94.12 & 119 & 100.00 & \\
\hline \multicolumn{8}{|c|}{ Job Satisfaction } \\
\hline Low & 4 & 44.44 & 5 & 55.56 & 9 & 100.00 & \multirow{3}{*}{0.000} \\
\hline Tall & 3 & 2.73 & 107 & 97.27 & 110 & 100.00 & \\
\hline Total & 7 & 5.88 & 112 & 94.12 & 119 & 100.00 & \\
\hline
\end{tabular}

Table 4. Patient Safety Culture

\begin{tabular}{|c|c|c|c|c|c|c|c|}
\hline \multirow{3}{*}{$\begin{array}{c}\text { Variables And } \\
\text { Dimensions }\end{array}$} & \multicolumn{4}{|c|}{ Patient Safety Culture } & \multirow{2}{*}{\multicolumn{2}{|c|}{ Total }} & \multirow{3}{*}{$\begin{array}{c}\text { P- } \\
\text { Value }\end{array}$} \\
\hline & \multicolumn{2}{|c|}{ Low } & \multicolumn{2}{|c|}{ Tall } & & & \\
\hline & $\mathbf{N}$ & $\%$ & $\mathbf{N}$ & $\%$ & $\mathbf{N}$ & $\%$ & \\
\hline \multicolumn{8}{|c|}{ Directive } \\
\hline Low & 2 & 100.00 & 0 & 0.00 & 2 & 100.00 & \multirow{3}{*}{0.000} \\
\hline Tall & 5 & 4.27 & 112 & 95.73 & 117 & 100.00 & \\
\hline Total & 7 & 5.88 & 112 & 94.12 & 119 & 100.00 & \\
\hline \multicolumn{8}{|c|}{ Supportive } \\
\hline Low & 3 & 33.33 & 6 & 66.67 & 9 & 100.00 & \multirow{3}{*}{0.000} \\
\hline Tall & 4 & 3.64 & 106 & 96.36 & 110 & 100.00 & \\
\hline Total & 7 & 5.88 & 112 & 94.12 & 119 & 100.00 & \\
\hline \multicolumn{8}{|c|}{ Participatory } \\
\hline Low & 3 & 33.33 & 6 & 66.67 & 9 & 100.00 & \multirow{3}{*}{0.000} \\
\hline Tall & 4 & 3.64 & 106 & 96.36 & 110 & 100.00 & \\
\hline Total & 7 & 5.88 & 112 & 94.12 & 119 & 100.00 & \\
\hline
\end{tabular}




\begin{tabular}{|c|c|c|c|c|c|c|c|}
\hline \multicolumn{8}{|c|}{ Achievement Oriented } \\
\hline Low & 1 & 100.00 & 0 & 0.00 & 1 & 100.00 & \multirow{3}{*}{0.000} \\
\hline Tall & 6 & 5.08 & 112 & 94.92 & 118 & 100.00 & \\
\hline Total & 7 & 5.88 & 112 & 94.12 & 119 & 100.00 & \\
\hline \multicolumn{8}{|c|}{ Leadership } \\
\hline Low & 3 & 42.86 & 4 & 57.14 & 7 & 100.00 & \multirow{3}{*}{0.000} \\
\hline Tall & 4 & 3.57 & 108 & 96.43 & 112 & 100.00 & \\
\hline Total & 7 & 5.88 & 112 & 94.12 & 119 & 100.00 & \\
\hline
\end{tabular}

Table 3 shows the relationship between the independent variable and the dependent variable. Based on the results of the analysis, it can be seen that there is a relationship with management on the variable job satisfaction of nurses on patient safety culture, there is an influence of directive, supportive, participatory, achievement-oriented dimensions on the leadership variable on patient safety culture in Lagaligo I Hospital, East Luwu Regency.

Table 4. Test Results Influence Together Variable Job Satisfaction and Variable Leadership on Patient Safety Culture in Nurses in RSUD I Lagaligo East Luwu District year 2021

\begin{tabular}{|l|l|l|l|l|l|}
\hline \multirow{2}{*}{ Model } & \multicolumn{2}{|c|}{$\begin{array}{c}\text { Unstandardized } \\
\text { Coefficients }\end{array}$} & $\begin{array}{c}\text { Standardized } \\
\text { Coefficients }\end{array}$ & \multirow{2}{*}{ T } & \multirow{2}{*}{ Itself. } \\
\cline { 2 - 5 } & B & $\begin{array}{c}\text { Std. } \\
\text { Error }\end{array}$ & Beta & & \\
\hline (Constant) & 1.170 & 0.160 & & 7.301 & 0.000 \\
\hline Job Satisfaction & 0.473 & 0.150 & 0.531 & 3.150 & 0.002 \\
\hline Leadership & -0.071 & 0.169 & -0.071 & -0.424 & 0.673 \\
\hline
\end{tabular}

Table 4 shows that it can be seen that the results of the $\mathrm{T}$ test on the satisfaction dimension show that the job satisfaction variable shows a p value (Sig) of 0.002 less than 0.05 . Which means that the job satisfaction variable has a significant and positive influence of 0.473 on the culture of patient safety in nurses at Lagaligo I Hospital, East Luwu Regency. Thus, it can be concluded that any increase in job satisfaction will have an effect on increasing the patient safety culture by 0.439 . The leadership variable shows a p value (Sig) of 0.673 , greater than 0.05 . Which means that the leadership variable does not have a significant effect on the culture of patient safety in nurses at Lagaligo I Hospital, East Luwu Regency.

Research hypothesis 1 (H1) states that there is an effect of job characteristics on job satisfaction on safety culture. Based on the statistical analysis carried out, it is known that the effect of job characteristics on job satisfaction on safety culture in Lagaligo I Hospital, East Luwu Regency. A significant effect is also indicated by a significance value of 0.000 so that in this case the research hypothesis $1(\mathrm{H} 1)$ is accepted.

Health workers have an important role in creating quality health services and are oriented towards patient safety. Among other things, in implementing a patient safety culture. Currently patient safety has not fully become a culture in health services. This can be seen from the existence of cases such as malpractice, discrimination, and others. Every health profession has its own code of ethics. The existence of a code of conduct should be an aspect of implementing a patient safety culture. Hospital Law Number 44 of 2009 clearly states that patient safety is a factor that must be prioritized by health workers compared to other factors. 
Mahayanti \& Sriathi (2017) defines job characteristics as the number of responsibilities, variations in tasks and jobs that have characteristics where people get satisfaction. Satisfaction with the job will motivate everyone from feeling dissatisfied. Job satisfaction is influenced by job characteristics which are the basis of work activities and design on job satisfaction has an important role in the success and sustainability of the company. This statement is in line with the explanation of Luthans (2006) in Lubis (2017) Dicky Januardi \& Budiono. The Effect of Job Characteristics on Job Satisfaction through Organizational Commitment suggests that job characteristics are one of several factors that influence job satisfaction.

Research conducted in recent years, such as that conducted by Tamaka et al., (2017) at PT. Bank Mandiri and Nur (2018) at PT. Mahakam Sawit Plantation explained that there is a positive relationship between job characteristics and job satisfaction. However, a contradiction was found by Kadir et al., (2017) with the explanation that there was no relationship between job characteristics and employee job satisfaction.

Research hypothesis $2(\mathrm{H} 2)$ states that there is an effect of reward on job satisfaction on safety culture. Based on the statistical analysis carried out, it is known that the effect of reward on job satisfaction on safety culture in Lagaligo I Hospital, East Luwu Regency. A significant effect is also indicated by a significance value of 0.000 so that in this case the research hypothesis $2(\mathrm{H} 2)$ is accepted.

An important factor that needs to be considered by management in managing human resources is appreciation. Awards are considered important because giving awards to employees can show the company's concern for managers. With this award, employees will feel treated as normal individuals, meaning they do not become laborers. The existence of this award can ultimately motivate managers to improve their work performance and morale so that employee job satisfaction can be achieved.

This proves or supports research conducted by Anggrainie (2013) which states that rewards have a significant effect on job satisfaction. Siswanto (2000) award is an acknowledgment of an achievement that has been achieved by someone who will be a strong motivator. Recognition of an achievement, will provide higher satisfaction than in the form of materials or gifts.

Research hypothesis $3(\mathrm{H} 3)$ states that there is an influence of the work environment on job satisfaction on safety culture. Based on the statistical analysis carried out, it is known that the influence of the work environment on job satisfaction on the culture of safety in Lagaligo I Hospital, East Luwu Regency. A significant effect is also indicated by a significance value of 0.000 so that in this case the research hypothesis 3 (H3) is accepted.

Management often does not pay much attention to the work environment because they think that the salary is what employees need the most. If seen from several cases, many work environments that are not supportive have resulted in employee accidents, such as fires, work accidents. This is of course very detrimental to the employees themselves. With a comfortable and guaranteed work environment it will impact on the safety of its employees.

Nurses are health service agents who play a structural role and carry a mission for a better organizational change. So that in line with this, nurses are one of the key or determining factors in the health services of an organization at all levels of health service centers, if nurses are considered good, the service in an organization will also be good (Teixeira \& Barbieri-Figueiredo, 2015). Various issues that occur in the scope of nursing and 
health services require the managerial level of nursing to improve the work environment of nurses, increase nurse retention, and increase nurse satisfaction, so that it will have a positive impact on the quality of health services provided (Bawafaa, Wong, \& Laschinger, 2015).

Research hypothesis 4 (H4) states that there is a management effect on job satisfaction on safety culture. Based on the statistical analysis conducted, it is known that the influence of management on job satisfaction on safety culture in Lagaligo I Hospital, East Luwu Regency. A significant effect is also indicated by a significance value of 0.000 so that in this case the research hypothesis 4 (H4) is accepted.

The task for management is to ensure that employees have high morale and morale and are resilient at work. Usually employees who are satisfied with what they get from the company will give more than what is expected and they will continue to try to improve their performance, on the other hand, employees with low job satisfaction tend to see work as tedious and boring, so they work forced and carelessly. . For this reason, it is imperative for organizations to recognize what factors make employees satisfied working in a company / agency.

Research hypothesis 5 (H5) states that there is a directive effect on leadership on safety culture. Based on the statistical analysis carried out, it is known that the effect of directives on leadership on the culture of safety in Lagaligo I Hospital, East Luwu Regency. A significant effect is also indicated by a significance value of 0.000 so that in this case the research hypothesis 5 (H5) is accepted.

One important concept of thought about patient safety, namely leadership thinking, is a step to optimize the patient safety movement in the hospital, carried out by forming a collaboration between all policy makers in the hospital. Leadership produces a patient safety culture, so a leader must always make continuous efforts to prevent injuries to patients and employees (Byers, 2004).

Leadership produces a culture of safety, a leader must always make continuous efforts to prevent injury to patients and hospital staff (Krausse \& Hidley, 2009). Board of directors, managers, and clinical service coordinators must work together with serious, visible and high commitment.

Research hypothesis 6 (H6) states that there is a supportive influence on leadership on safety culture. Based on the statistical analysis carried out, it is known that the supportive influence of leadership on the culture of safety in Lagaligo I Hospital, East Luwu Regency. A significant effect is also indicated by a significance value of 0.000 so that in this case the research hypothesis $6(\mathrm{H} 6)$ is accepted.

Building a culture of patient safety in the hospital is the duty and responsibility of all staff, especially those who deal directly with patients, namely doctors and nurses. Hamdani's research (2007) shows that nurses are a component of health workers (profession) that is most associated with the implementation of patient safety. Several studies reported the role of senior leadership as a key factor in shaping patient safety culture. The role of the head of the room as a leader in the room is very vital.

Research hypothesis 7 (H7) states that there is a participatory influence on leadership on safety culture. Based on the statistical analysis carried out, it is known that the participatory influence of leadership on the culture of safety in Lagaligo I Hospital, East Luwu Regency. A significant effect is also indicated by a significance value of 0.000 so that in this case the research hypothesis 7 (H7) is accepted. 
The results of the research by Nivalinda (2013) showed a strong effect $(r=0.607)$ and a positive pattern. This means that the more effective the leadership style of the head of the office, the better the application of patient safety culture. Leaders who are effective in applying a certain leadership style need to adapt their leadership style to the characteristics of their subordinates and situations, and combine several leadership styles depending on the situation and conditions at hand. The percentage of the influence of the head of room leadership style variable on the application of patient safety culture in this study was $36.8 \%$. The successful implementation of clinical innovation requires not only effective leadership support, but also requires organizational support and implementation tools.

Research hypothesis 8 (H8) states that there is a participatory influence on leadership on safety culture. Based on the statistical analysis carried out, it is known that the participatory influence of leadership on the culture of safety in Lagaligo I Hospital, East Luwu Regency. A significant effect is also indicated by a significance value of 0.000 so that in this case the research hypothesis 8 (H8) is accepted.

An effective leader applies a certain style of leadership to fulfill several principles which are covered in supportive, directive, participatory and achievement orientation leadership styles. This principle includes being able to recognize the needs of subordinates, stimulate and try to meet these needs, and provide rewards for success in achieving goals. Leaders must be able to help subordinates identify the most effective way and provide clear paths for subordinates to achieve goals by providing maximum guidance and direction. Leaders must try to reduce barriers in the process of achieving subordinate performance goals. Leaders must try to increase the opportunity for subordinates to feel personal satisfaction through the achievement of effective performance. Leaders who can implement these things will find it easier for subordinates to achieve their performance goals effectively (Martin et al, 2009).

Research hypothesis 8 (H8) states that there is job satisfaction and leadership towards patient safety culture. Based on the statistical analysis carried out, it is known that the participatory influence of leadership on the culture of safety in Lagaligo I Hospital, East Luwu Regency. A significant effect is also indicated by the significance values of 0.002 and 0.673 so that in this case the research hypothesis 8 (H8) is accepted.

Employees who are satisfied with what is obtained from the company will provide more than what the company expects with high commitment and they will continue to strive to improve their performance. Conversely, employees whose job satisfaction is low, tend to see work as boring and boring, so they work carelessly and not wholeheartedly. Job satisfaction is seen in the positive attitude of employees towards their work and everything they face in their work environment, on the other hand, employees who are not satisfied by the dimensions related to work appear to have negative attitudes which reflect their lack of commitment to the company such as frequent absenteeism, low productivity, high the level of damage, employee displacement, anxiety and the occurrence of demands that end in a strike.

Nurses who feel satisfied in their work will provide better and quality service to patients in the hospital so that patient satisfaction and the patient's family are also fulfilled, which in turn can improve the image and income of the hospital. Measuring job satisfaction of nurses is not only important for knowing the performance of the hospital, especially in its workforce, but also for determining future management strategies. 


\section{Conclusion}

The results showed that there was an influence of job characteristics, rewards, work environment, relationship with management on the variable job satisfaction of nurses on patient safety culture, there was an influence of directive, supportive, participatory, achievement-oriented dimensions on leadership variables on patient safety culture, and job satisfaction of nurses. jointly influence the culture of patient safety in RSUD I Lagaligo, East Luwu Regency. Therefore, it is hoped that the hospital will pay more attention to a safe and comfortable work environment and for leadership it is expected to set standards for developing competency through trainings, solving any existing problems quickly and responsively.

\section{References}

Asegid, A., Belachew, T., \& Yimam, E. (2014). Factors Influencing Job Satisfaction and Anticipated Turnover among Nurses in Sidama Zone Public Health Facilities, South Ethiopia. Nursing Research and Practice, 2014(February), 1-26. https://doi.org/10.1155/2014/909768

Association of periOperative Registered Nurses. (2006). ORN guidance statement: Creating a patient safety culture. AORN Journal, 83(4), 936-941.

Dicuccio, M. H. (2015). The Relationship between Patient Safety Culture and Patient Outcomes: A Systematic Review. Journal of Patient Safety, 11(3), 135-142. https://doi.org/10.1097/PTS.0000000000000058

Duffy, W. (2017). Improving Patient Safety by Practicing in a Just Culture. AORN Journal, 106(1), 66-68. https://doi.org/10.1016/j.aorn.2017.05.005

Enfoque, E. L., Monitoreo, D. E. L., Gallego, I., Proyecto Jalda, R. Villalta, A. C., Tapella, E., Gohl, E., Mendoza, R., Melorose, J., Perroy, R., Careas, S., Alianza internacional contra el VIH/SIDA, Centro de Investigación y desarrollo de la educación., María Antonia Rodríguez Arce, Campilan, D., Gaventa, J., Gonsalves, J., Guijt, I., Johnson, D., ... Gómez, V. (2010). No Title“거대한 잠재력” 인도.아세안 본격 공략 시동. International Institute for Environment and Development, 07/80(2), 125. https://arxiv.org/pdf/1707.06526.pdf

Inoue, T., Karima, R., \& Harada, K. (2017). Bilateral effects of hospital patient-safety procedures on nurses' job satisfaction. International Nursing Review, 64(3), 437445. https://doi.org/10.1111/inr.12336

Luthans, F. (2006). Perilaku organisasi (edisi 10).

Moody, R. F., Pesut, D. J., \& Harrington, C. F. (2006). Creating Safety Culture on Nursing Units. Journal of Patient Safety, 2(4), 198-206. https://doi.org/10.1097/01.jps.0000242978.40424.24

Mutsani, R. (2013). Hubungan Persepsi dengan Kepuasan Pasien tentang Mutu Pelayanan Keperawatan di Ruang Rawat Inap Rumah Sakit Umum Daerah Wates Kulon Progo Yogyakarta. Stikes Jenderal Achmad Yani.

Nurdiana. (2018). Hubungan Motivasi Perawat dengan Kepatuhan Pendokumentasian Surgical Safety Checklist di Ruang Instalasi Bedah Rumah Sakit Wilayah Makassar [Universitas Islam Negeri Alauddin Makassar]. In UIN Alauddin Makassar (Vol. 48, 
Issue

2).

https://www.academia.edu/38922036/The_Integration_of_Technology_into_English _Language_Teaching_The_Underlying_Significance_of_LMS_in_ESL_Teaching_d espite_the_Ebb_and_Flow_of_Implementation?email_work_card=view-paper

Richardson, A Storr, J. (2010). Patient safety- a literative review on the impact of nursing empowerment, leadership and collaboration. International Nursing Review, 57, 1221.

Veramitha, Nydia. Suparwati, Anneke. Wigati, P. A. (2016). Persepsi Pasien Rawat Inap Klas III terhadap Responsiveness Pelayanan Dokter dan Perawat di Rumah Sakit Umum Daerah Raa Soewondo Pati. Jurnal Kesehatan Masyarakat (E-Journal), 4(1), 55-64. 